\title{
32. OXYGEN AND CARBON ISOTOPES FROM BULK CARBONATES AND FORAMINIFERAL SHELLS AT DSDP SITES 400, 401, 402, 403, AND 406
}

\author{
René Létolle, Colette Vergnaud Grazzini, and Catherine Pierre, Laboratoire de Géologie Dynamique, \\ Université Pierre et Marie Curie, Paris, France
}

\section{INTRODUCTION}

Oxygen and carbon isotope analyses have been performed on planktonic and benthic foraminifers from levels widely spaced in time ( 2 to $4 \mathrm{~m} . \mathrm{y}$.) at Hole $400 \mathrm{~A}$ and Site 401. In addition, oxygen and carbon isotope analyses of bulk carbonates from 250 levels from Holes 400A, 402A, and Sites 401, 403, and 406 (Figure 1) are interpreted in terms of paleoceanographic changes. Their evolution is compared with the thermal evolution that can be deduced from foraminiferal analyses.

Analyses on bulk carbonates are not a common practice because certain problems may rise, the most important being related to diagenetic or/and autolithification processes, and to the presence in the sediment of detrital carbonates. However, when it can be ensured that these two factors are absent (by Scanning Electron Microscope [SEM] and smear-slide observations), it is most probable that the

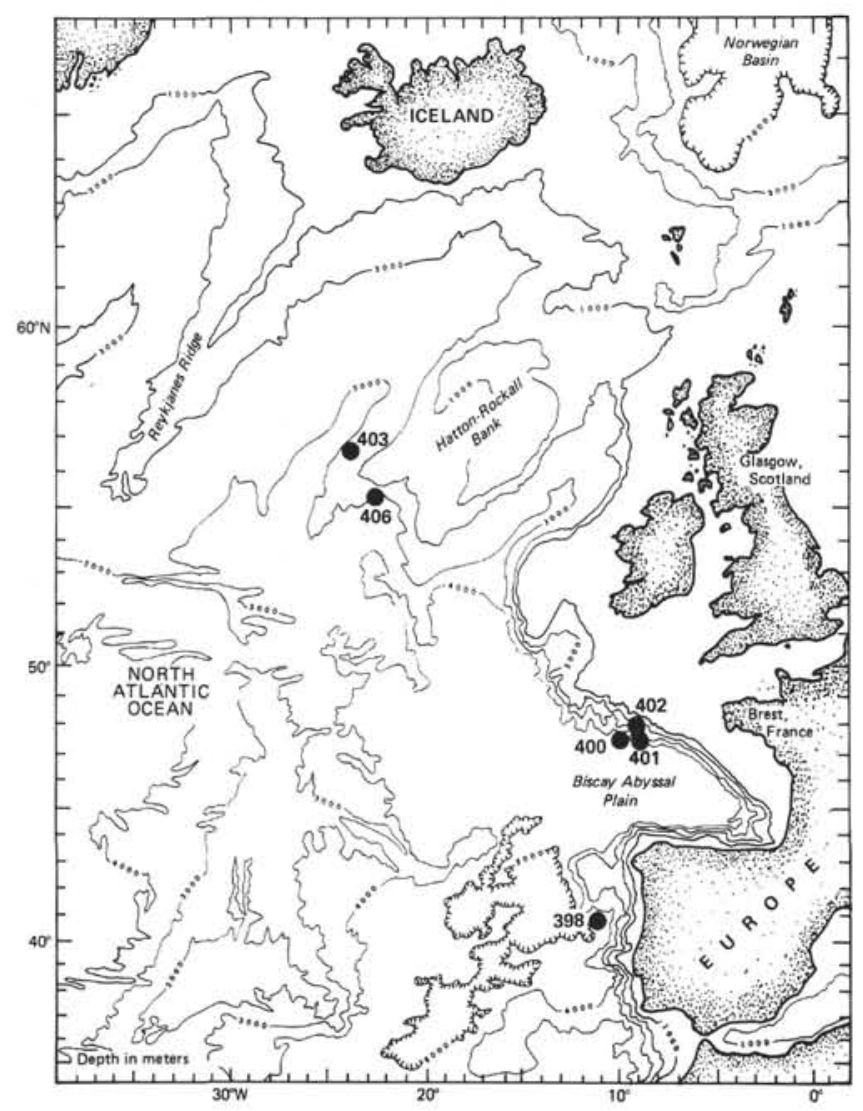

Figure 1. Location of the sites of sampling. bulk carbonate represents the total biogenic carbonates, i.e., planktonic + benthic foraminifers + calcareous nannofossils, principally Coccolithophoridae. Because the latter are, in terms of weight, the major contributors to pelagic sediments, the isotopic evolution deduced from bulk carbonates should reflect essentially the evolution of calcareous planktonic organisms. Since calcareous nannofossils deposit calcium carbonate at or near equilibrium with oceanic surface waters (Margolis et al., 1975), one should expect the evolution of oxygen and carbon isotopic composition of bulk carbonates, through time, to be more or less parallel to that of planktonic foraminifers.

\section{SAMPLE DISTRIBUTION}

Bulk carbonates were crushed and washed under distilled water, then dried for analysis at room temperature.

Where possible, monospecific samples of planktonic foraminifer, and mixed samples of two or more species of benthic forms (Oridorsalis, Melonis, Nuttalides) were hand-picked, cleaned from detrital material in an ultrasonic bath, and purified of organic matter by a 24 -hour one per cent Clorox treatment.

Carbon dioxide release and calibration procedure were identical to those described by Shackleton and Opdyke (1976). Isotope analyses were performed in a VG Micromass 602 mass spectrometer and calibrated by analysis of standard carbonate samples under identical conditions.

All results are reported in $\delta$ notation as per mil deviations from the PDB 1 standard. Precision of the analyses is generally better than 0.1 per mil. Replicate analyses on the same sample are within a range of 0.15 per mil for planktonic foraminifers and 0.20 per mil for bulk carbonates. Temperatures were calculated and the assumption that the isotope composition of sea water in which foraminiferal and coccoliths shells grew was -1.2 per mil relative to the PDB standard before the late Miocene $(\approx 11 \mathrm{~m} . \mathrm{y}$.) (Shackleton and Kennett, 1975); for samples younger than $11 \mathrm{~m} . y$., the isotopic composition of sea water was taken at $-0.2^{\%} \%$ on the PDB scale.

Because of the uncertainties in the isotopic composition of sea water, the calculated temperatures may be systematically a few degrees higher or lower than actual growth temperatures for part or all of the levels under study. Thus, temperature evaluations are regarded only for the purpose of clarity and illustration of the most pronounced tendencies.

The results of the investigation are reported in Tables 1 to 9 and plotted against depth in Figures 2 to 6. 
TABLE 1

Oxygen and Carbon Isotopic Data for Benthic Foraminifers From Hole $400 \mathrm{~A}^{\mathrm{a}}$

\begin{tabular}{|c|c|c|c|c|}
\hline Age & $\begin{array}{c}\text { Sample } \\
\text { (Interval in } \mathrm{cm} \text { ) }\end{array}$ & Genera & ${ }^{18} \mathrm{O}$ & ${ }^{13} \mathrm{C}$ \\
\hline NN 19 & $\begin{array}{l}2-2,114 \\
2-2,114 \\
5-1,86 \\
10-1,57 \\
10-1,57 \\
13-4,64\end{array}$ & $\begin{array}{l}\text { Melonis } \\
\text { Oridorsalis } \\
\text { Mixed species } \\
\text { Melonis } \\
\text { Oridorsalis } \\
\text { Mixed species }\end{array}$ & $\begin{array}{l}+3.16 \\
+3.51 \\
+2.28 \\
+2.63 \\
+2.49 \\
+3.59\end{array}$ & $\begin{array}{l}-1.43 \\
-0.98 \\
-1.15 \\
-1.25 \\
-0.18\end{array}$ \\
\hline NN 12 & $\begin{array}{l}14-3,22 \\
18-3,52 \\
23, \mathrm{CC}\end{array}$ & $\begin{array}{l}\text { Mixed species } \\
\text { Oridorsalis } \\
\text { Oridorsalis }+ \text { Melonis }\end{array}$ & $\begin{array}{l}+3.14 \\
+1.24 \\
+1.79\end{array}$ & $\begin{array}{l}-0.21 \\
-1.83 \\
-1.70\end{array}$ \\
\hline NN 10 & $24-6,67$ & Oridorsalis + Melonis & +1.11 & -1.75 \\
\hline NN 9 & $\begin{array}{l}26-3,65 \\
29-1,114 \\
30-1,98 \\
34, \text { CC }\end{array}$ & $\begin{array}{l}\text { Oridorsalis }+ \text { Melonis } \\
\text { Oridorsalis }+ \text { Melonis } \\
\text { Oridorsalis } \\
\text { Oridorsalis }+ \text { Melonis }\end{array}$ & $\begin{array}{l}+2.63 \\
+1.61 \\
+0.36 \\
-0.80\end{array}$ & $\begin{array}{l}-1.28 \\
-0.33 \\
-1.98 \\
-1.73\end{array}$ \\
\hline NN 6 & $35-3$ & Mixed species & -0.55 & -0.15 \\
\hline NN 2 & $\begin{array}{l}37-1 \\
39-1,117 \\
43-2,65 \\
43-5,65 \\
43, C C \\
44-1,69 \\
45-5,20\end{array}$ & $\begin{array}{l}\text { Oridorsalis } \\
\text { Oridorsalis } \\
\text { Oridorsalis } \\
\text { Mixed species } \\
\text { Mixed species } \\
\text { Mixed species } \\
\text { Mixed species }\end{array}$ & $\begin{array}{l}+1.23 \\
+1.72 \\
+1.69 \\
+1.18 \\
+1.64 \\
+0.94 \\
+0.94\end{array}$ & $\begin{array}{l}-0.49 \\
-0.22 \\
-0.36 \\
-1.41 \\
+0.34 \\
-0.32 \\
+0.13\end{array}$ \\
\hline NP 21 & $\begin{array}{l}45, \mathrm{CC} \\
47-6,97 \\
51-6,93 \\
54, \mathrm{CC} \\
56-2,60\end{array}$ & $\begin{array}{l}\text { Oridorsalis } \\
\text { Oridorsalis }+ \text { Melonis } \\
\text { Nuttalides } \\
\text { Oridorsalis }+ \text { Nuttalides } \\
\text { Oridorsalis }+ \text { Nuttalides }\end{array}$ & $\begin{array}{l}+1.03 \\
-0.24 \\
-1.77 \\
-1.39 \\
-0.94\end{array}$ & $\begin{array}{l}-1.10 \\
-1.58 \\
-0.13 \\
-1.88 \\
-0.58\end{array}$ \\
\hline NP 11 & $57-2$ & Melonis + Oridorsalis & +0.93 & +0.41 \\
\hline
\end{tabular}

${ }^{\mathrm{a}}$ Expressed as deviation per mil from PBD.

TABLE 2

Oxygen and Carbon Isotopic Data for Planktonic Foraminifers From Hole $400 \mathrm{~A}^{\mathrm{a}}$

\begin{tabular}{lllll}
\hline \multirow{2}{*}{ Age } & \multicolumn{1}{c}{$\begin{array}{c}\text { Sample } \\
\text { (Interval in cm) }\end{array}$} & \multicolumn{1}{c}{ Species } & $\delta^{18} \mathrm{O}$ & ${ }^{13} \mathrm{C}$ \\
\hline \multirow{2}{*}{ NN 19 } & $1-1,74$ & Orbulina universa & +0.58 & +1.90 \\
& $2-2,78$ & Orbulina universa & -1.00 & +0.69 \\
& $2-4,56$ & Orbulina universa & +1.95 & +1.52 \\
& $2-6,60$ & Orbulina universa & +2.21 & +1.43 \\
& $3-4,84$ & Orbulina universa & +1.95 & +2.22 \\
& $5-1,26$ & Orbulina universa & +1.44 & +1.56 \\
& $10-1,57$ & Orbulina universa & +0.59 & +0.50 \\
& $13-4,64$ & Orbulina universa & +0.94 & +1.24 \\
& & Orbulina universa & +1.38 & +1.52 \\
NN 12 & $14-3,22$ & Orbulina universa & +0.62 & +1.07 \\
& $16-1,143$ & Orbulina universa & +1.00 & +1.27 \\
& $18-3,52$ & Orbulina universa & -0.13 & +0.73 \\
& $24-6,67$ & Orbulina universa & -0.56 & +0.42 \\
NN 9 & $25, \mathrm{CC}$ & Orbulina universa & +0.64 & +0.86 \\
& $26-1,114$ & Globigerinita glutinata & -0.52 & +1.61 \\
NP 15 & $50, \mathrm{CC}$ & Mixed Globigerina & -0.27 & -0.34 \\
& $53, \mathrm{CC}$ & Mixed planktonic species & -1.13 & +0.93 \\
& $62-6,8$ & Rotalipora ticinensis & -1.57 & +1.01 \\
Cretaceous & & & & \\
\hline
\end{tabular}

${ }^{\mathrm{a}}$ Expressed as deviation per mil from PDB.

\section{Jurassic Isotopic Values (Site 401)}

It can be deduced from a comparison of our limited results with those obtained for previous Legs 11 (Brenneke, 1978) and 44 (Létolle et al., in preparation) that hydrothermal influences did not affect the Jurassic
TABLE 3

Oxygen and Carbon Isotopic Data for Benthic Foraminifers From Site $401^{\mathrm{a}}$

\begin{tabular}{llllc}
\hline Age & $\begin{array}{c}\text { Sample } \\
\text { (Interval in cm) }\end{array}$ & \multicolumn{1}{c}{ Genera } & ${ }^{18} \mathrm{C}$ & ${ }^{13} \mathrm{C}$ \\
\hline NN 19 & $1-1,11$ & Melonis & +2.10 & -0.78 \\
NP 21 & 2, CC & Nuttalides & +1.13 & +0.55 \\
NP 19 & 3, CC & Nuttalides + Oridorsalis & +0.82 & - \\
& 4, CC & Oridorsalis & +0.10 & - \\
& $5-3,119$ & Oridorsalis + Nuttalides & +1.26 & -0.49 \\
NP 15 & $9-6,72$ & Nuttalides & -0.25 & -0.77 \\
& $11-4,72$ & Mixed species & -0.28 & -1.57 \\
NP 10 & 13, CC & Oridorsalis + Nuttalides & +0.41 & +0.10 \\
NP 9 & 14, CC & Oridorsalis + Nuttalides & +1.63 & +2.42 \\
NP 3 & 17, CC & Mixed species & +0.55 & +0.73 \\
& & & & \\
\hline
\end{tabular}

${ }^{\mathrm{a}}$ Expressed as deviation per mil from PDB.

TABLE 4

Oxygen and Carbon Isotopic Data for Planktonic Foraminifers From Site $401^{\mathrm{a}}$

\begin{tabular}{|c|c|c|c|c|}
\hline Age & $\begin{array}{c}\text { Sample } \\
\text { (Interval in } \mathrm{cm} \text { ) }\end{array}$ & Species & ${ }^{18} \mathrm{O}$ & ${ }_{8}^{13} \mathrm{C}$ \\
\hline NP 21 & $\begin{array}{l}2, \mathrm{CC} \\
3, \mathrm{CC} \\
4, \mathrm{CC} \\
5-3,119 \\
6, \mathrm{CC} \\
7-5,87\end{array}$ & $\begin{array}{l}\text { Catapsydrax unicava } \\
\text { Globigerinatheca index } \\
\text { Globigerinatheca index } \\
\text { Catapsydrax unicava } \\
\text { Catapsydrax unicava } \\
\text { Globigerinatheca index } \\
\text { Globigerina linaperta } \\
\text { Globigerina linaperta } \\
\text { Globigerinatheca index } \\
\text { Globigerina linaperta }\end{array}$ & $\begin{array}{l}-0.05 \\
-0.46 \\
-0.69 \\
-0.07 \\
-0.39 \\
-1.29 \\
-1.01 \\
-1.38 \\
-1.83 \\
-1.14\end{array}$ & $\begin{array}{l}+1.15 \\
-1.08 \\
+1.38 \\
+1.19 \\
-1.08 \\
+2.05 \\
- \\
+2.09 \\
+1.14 \\
+0.30\end{array}$ \\
\hline NP 15 & $\begin{array}{l}9-6,72 \\
11-4,95\end{array}$ & $\begin{array}{l}\text { Globigerina linaperta } \\
\text { Globigerina linaperta }\end{array}$ & $\begin{array}{l}-0.47 \\
-2.00\end{array}$ & $\begin{array}{l}-1.18 \\
+0.60\end{array}$ \\
\hline NP 10 & $13, \mathrm{CC}$ & $\begin{array}{l}\text { Globigerina linaperta } \\
\text { Subbotina }\end{array}$ & $\begin{array}{l}-1.95 \\
-1.41\end{array}$ & $\begin{array}{l}+0.73 \\
+1.44\end{array}$ \\
\hline NP 9 & $14, \mathrm{CC}$ & $\begin{array}{l}\text { Globigerina venezuelana } \\
+ \text { Globigerina linaperta } \\
\text { Mixed planktonic species }\end{array}$ & $\begin{array}{l}-0.58 \\
-0.24\end{array}$ & $\begin{array}{l}+2.12 \\
+2.11\end{array}$ \\
\hline NP 3 & $\begin{array}{l}16, \mathrm{CC} \\
17, \mathrm{CC}\end{array}$ & $\begin{array}{l}\text { Globigerina triloculinoides } \\
\text { Subbotina } \\
\text { Mixed species }\end{array}$ & $\begin{array}{l}-1.71 \\
-0.12 \\
-0.17\end{array}$ & $\begin{array}{l}+0.84 \\
+1.41 \\
+1.40\end{array}$ \\
\hline
\end{tabular}

${ }^{\mathrm{a}}$ Expressed as deviation per mil from PDB.

sediments at Site 401. Small fluctuations cannot be interpreted because of the numerous sedimentation gaps in the section.

\section{Cretaceous Isotopic Values (Holes 400A, 402A)}

During Aptian/Albian time at Sites 400 and 402, the isotopic compositions were relatively steady; small variations occur around an average of $-2 \%$. Low oxygen isotopic values were obtained for planktonic foraminifers from Samples 62-1, $70 \mathrm{~cm}$ (Planomalina buxtorfi) and 69, CC (Hedbergella trocoidea) in Hole 400A; these values, ranging between $-4 \%$ and $-6 \%$, may be the result of diagenetic alteration. One species, Rotalipora ticinensis, was better preserved, and occurs at Sample $62-6,8 \mathrm{~cm}$ in Hole $400 \mathrm{~A}$ with a $\delta^{18} \mathrm{O}$ of $-1.57^{\circ} \%$. If we assume the $\delta^{18} \mathrm{O}$ of the water to be around $-1.2 \%$ (Shackleton and Kennett, 1975), we arrive at a temperature estimate higher 
TABLE 5

Oxygen and Carbon Isotopic Data for Bulk Carbonates From Hole $400 \mathrm{~A}^{\mathrm{a}}$

\begin{tabular}{|c|c|c|c|c|}
\hline $\begin{array}{c}\text { Sample } \\
\text { (Interval in } \mathrm{cm} \text { ) }\end{array}$ & Age & ${ }_{8}^{13} \mathrm{C}$ & ${ }^{18} \mathrm{O}$ & Remarks \\
\hline $1-1,13-14$ & Pleistocene & +0.39 & +0.83 & \\
\hline $1-1,48-50$ & & +1.29 & +2.01 & Marly nannofossil ooze \\
\hline $1-2,16-18$ & & +1.83 & +2.07 & \\
\hline $1-5,86$ & & -0.25 & -0.87 & \\
\hline $2-1,54$ & & +0.48 & -2.31 & \\
\hline $\begin{array}{l}2-1,91 \\
2-2,30\end{array}$ & & $\begin{array}{l}+0.60 \\
+0.19\end{array}$ & $\begin{array}{l}+1.09 \\
+0.12\end{array}$ & Nannofossil ooze \\
\hline $\begin{array}{l}2-2,30 \\
2-2,54-56\end{array}$ & & +0.17 & +3.04 & \\
\hline $2-2,100$ & & +0.34 & +1.53 & \\
\hline $2-3,54-56$ & & +0.91 & +3.00 & \\
\hline $2-3,80$ & & +0.42 & +0.62 & \\
\hline $2-4,15$ & & +0.75 & +1.63 & \\
\hline $2-4,54-56$ & & +1.29 & +4.20 & \\
\hline $2-4,108$ & & -0.08 & +1.55 & \\
\hline $2-5,54-56$ & & +0.89 & +2.17 & \\
\hline $2-5,90$ & & +0.61 & +1.95 & \\
\hline $2-6,15$ & & +0.31 & +1.86 & \\
\hline $\begin{array}{l}2-6,60-62 \\
3-1,84-86\end{array}$ & & $\begin{array}{l}+0.51 \\
+0.67\end{array}$ & $\begin{array}{l}+2.12 \\
+2.29\end{array}$ & Marly nannofossil ooze \\
\hline $\begin{array}{l}3-1,84-86 \\
3-1,90\end{array}$ & & $\begin{array}{l}+0.67 \\
+0.28\end{array}$ & $\begin{array}{r}+2.29 \\
+1.75\end{array}$ & \\
\hline $\begin{array}{l}3-1,90 \\
3-2,40\end{array}$ & & +0.52 & +2.06 & \\
\hline $3-2,84-86$ & & +1.08 & +2.97 & \\
\hline $3-2,100$ & & +0.45 & +1.54 & \\
\hline $3-3,50$ & & +0.51 & +2.25 & \\
\hline $3-3,78-79$ & & -0.52 & +0.11 & \\
\hline $3-3,84-86$ & & +0.24 & +3.86 & \\
\hline $3-3,100$ & & -0.14 & +1.07 & \\
\hline $3-4,30-32$ & & -0.17 & +1.61 & \\
\hline $3-4,84-86$ & & +0.39 & +1.64 & \\
\hline $\begin{array}{l}3-4,90 \\
3, \mathrm{CC}\end{array}$ & & $\begin{array}{l}+0.27 \\
+0.06\end{array}$ & $\begin{array}{l}+1.80 \\
+1.09\end{array}$ & \\
\hline $\begin{array}{l}3, \mathrm{CC} \\
4-1,75\end{array}$ & & +0.15 & +1.59 & \\
\hline $\begin{array}{l}4-1,75 \\
4-2,90-92\end{array}$ & & -0.23 & +2.32 & \\
\hline $4-3,100-102$ & Late Pliocene & +0.16 & +1.60 & Nannofossil ooze \\
\hline $4-4,50$ & & +0.69 & -1.31 & \\
\hline $4-4,90$ & & +0.09 & +1.37 & \\
\hline $4-5,16$ & & -0.12 & +1.39 & \\
\hline $\begin{array}{l}4-5,148 \\
4, C C\end{array}$ & & $\begin{array}{l}-0.52 \\
-0.31\end{array}$ & $\begin{array}{l}+1.35 \\
+1.44\end{array}$ & \\
\hline $\begin{array}{l}4, \mathrm{CC} \\
5-1,30-31\end{array}$ & & $\begin{array}{l}-0.31 \\
+0.16\end{array}$ & $\begin{array}{l}+1.44 \\
+1.36\end{array}$ & \\
\hline $5-1,50$ & & -0.94 & +0.16 & \\
\hline $5 \cdot 1,148$ & & +0.32 & +1.79 & \\
\hline $5-2,35$ & & & +1.91 & \\
\hline $6-1,130$ & & +0.24 & +2.51 & \\
\hline $6-2,30$ & & +0.59 & +2.08 & \\
\hline $6-2,100$ & & -0.24 & +1.72 & \\
\hline $6 \cdot 3,30$ & & & +1.87 & \\
\hline $6-3,100$ & & +0.17 & +1.71 & \\
\hline $\begin{array}{l}6, \mathrm{CC} \\
7-1,140\end{array}$ & & +0.42 & $\begin{array}{l}+1.88 \\
+1.72\end{array}$ & \\
\hline $\begin{array}{l}7-1,140 \\
7-2,30\end{array}$ & & $\begin{array}{r}70.42 \\
+0.28\end{array}$ & $\begin{array}{r}+1.72 \\
+1.93\end{array}$ & \\
\hline $\begin{array}{l}7-2,30 \\
7-2,110\end{array}$ & & +0.72 & +1.94 & \\
\hline $7-3,30-32$ & & +0.23 & +1.49 & \\
\hline $8-1,100$ & & -0.23 & +1.67 & \\
\hline $8-3,34-36$ & & +0.49 & +1.37 & \\
\hline $8-3,40$ & & +0.07 & +1.69 & \\
\hline $8-5,112-114$ & & +0.30 & +1.85 & \\
\hline $9-3,30$ & & -0.21 & +1.20 & \\
\hline $9-3,40-42$ & & +0.53 & +1.58 & \\
\hline $9-5,100$ & & -0.07 & +1.29 & \\
\hline $9-6,100$ & & +0.48 & +2.54 & \\
\hline $10-2,118-120$ & Early Pliocene & -0.07 & +1.66 & \\
\hline $11-2,18-20$ & & +1.08 & +1.76 & \\
\hline $12-3,47-49$ & & +0.81 & +2.02 & \\
\hline $13-4,57-59$ & & +0.23 & +1.77 & \\
\hline $14-1,63-65$ & $\begin{array}{l}\text { Early Pliocene or } \\
\text { late Miocene }\end{array}$ & +0.17 & +1.45 & Nannofossil chalk \\
\hline $15-2,60-62$ & & +0.12 & +1.45 & \\
\hline $17-2,113-115$ & & +0.94 & +1.52 & \\
\hline $18-3,73-75$ & & +0.78 & +1.89 & \\
\hline $19-2,86-88$ & & +0.52 & +1.30 & \\
\hline $20-3,95-97$ & & +0.68 & +1.76 & \\
\hline $21-4,43-47$ & & +1.16 & +1.74 & \\
\hline $22-2,65-67$ & & +1.00 & +1.42 & Marly nannofossil chalk \\
\hline $23-3,90-92$ & & +0.77 & +1.21 & \\
\hline $24-4,59-61$ & & +0.43 & +0.97 & \\
\hline $25-6,109-111$ & & +0.63 & +1.35 & \\
\hline $30-1,58-60$ & & +1.35 & +1.42 & \\
\hline $31-1,50-52$ & & +1.74 & +1.61 & \\
\hline $35-2,62-64$ & & +1.86 & +1.16 & \\
\hline $36-1,45-47$ & Early Miocene & +1.54 & +0.53 & \\
\hline $37-1,31-32$ & & +1.49 & +0.85 & \\
\hline $39-1,135-137$ & & +1.36 & +0.94 & \\
\hline $40, \mathrm{CC}, 71-76$ & & +1.47 & +0.98 & Siliceous nannofossil chalk \\
\hline $41-1,16-18$ & & +1.29 & +0.49 & \\
\hline $43-3,104-106$ & Middle-late Oligocene & +1.27 & +0.29 & Marly nannofossil chalk \\
\hline $44-1,85-87$ & & +1.06 & +0.31 & \\
\hline $44-1,105-106$ & & +0.92 & +0.85 & \\
\hline
\end{tabular}

TABLE 5 - Continued

\begin{tabular}{|c|c|c|c|c|}
\hline $\begin{array}{c}\text { Sample } \\
\text { (Interval in } \mathrm{cm} \text { ) }\end{array}$ & Age & $\delta^{13} \mathrm{C}$ & ${ }_{5}^{18} \mathrm{O}$ & Remarks \\
\hline $45-2,78-80$ & Early Oligocene & +0.90 & +1.74 & \\
\hline $45-3,110-112$ & & +1.09 & +0.79 & \\
\hline $46-4,71-73$ & & +1.80 & +0.98 & \\
\hline $46-5,140-142$ & & +2.13 & +0.87 & \\
\hline $47-6,106-108$ & Middle Eocene & +1.66 & -0.22 & \\
\hline $48-2,109-111$ & & +1.72 & +0.20 & Chalk conglomerate \\
\hline $50-4,119-121$ & & +1.63 & -0.70 & Siliceous mudstone \\
\hline $51-4,137-141$ & & +1.77 & -1.00 & \\
\hline $53-1,69-73$ & Early Eocene & +2.17 & -1.05 & \\
\hline $54-3,103-105$ & & +1.62 & -1.70 & \\
\hline $55-2,89-91$ & & +1.01 & -1.34 & \\
\hline $57-2,17-19$ & Late Paleocene & +1.21 & -1.91 & \\
\hline $59-1,23-24$ & & +2.96 & -0.52 & \\
\hline $59-1,68-71$ & & +2.90 & -0.54 & \\
\hline $60-6,141-143$ & Maestrichtian & +2.54 & 0.00 & Marly calcareous chalk \\
\hline $60-7,19-21$ & & +2.43 & -0.25 & \\
\hline $61, \mathrm{CC}$ & & +2.58 & -0.24 & \\
\hline $62-1,16$ & & +2.05 & -1.65 & \\
\hline $62-1,49-52$ & & +1.84 & -2.27 & \\
\hline $62-1,70-73$ & $\begin{array}{l}\text { Early Cretaceous/ } \\
\text { late Albian? }\end{array}$ & +1.80 & -2.55 & \\
\hline $62-2,24-25$ & & +1.80 & -2.31 & Sapropelic chalk \\
\hline $62-5,24-27$ & & +2.11 & -2.10 & \\
\hline $62-6,8-11$ & & +2.21 & -2.10 & \\
\hline $63-1,104-105$ & & +1.98 & -2.31 & \\
\hline $63-3,24-27$ & & +2.33 & -2.28 & \\
\hline $63-4,109 \cdot 110$ & & +1.94 & -1.38 & \\
\hline $64-5,70-71$ & Albian/late Aptian & +2.25 & -2.51 & \\
\hline $66-1,13-15$ & & +2.60 & -1.96 & \\
\hline $66-1,33-35$ & & +3.01 & -1.69 & \\
\hline $68-3,9-10$ & & +2.90 & -2.25 & Marly nannofossil chalk \\
\hline $69-1,103-104$ & & +3.79 & -1.40 & \\
\hline $69, \mathrm{CC}$ & & +4.15 & -1.26 & \\
\hline $71-1,98-99$ & Aptian & +2.34 & -1.48 & Calcareous mudstone \\
\hline $71-2,36-37$ & & +2.03 & -1.82 & \\
\hline $72-4,1-2$ & & +2.51 & -1.43 & \\
\hline $74-1,22-23$ & & +2.10 & -2.91 & \\
\hline
\end{tabular}

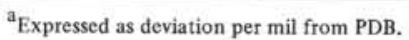

than $18^{\circ} \mathrm{C}$. Because we do not know the real ecological requirements of the species $R$. ticinensis, this evaluation remains an approximation. The temperature calculated for the bulk carbonate is about $20^{\circ} \mathrm{C}$. The rather high paleotemperatures indicated by oxygen isotopic measurements for the Cretaceous agree with the North Atlantic being, at that time, essentially a subtropical province (Berggren and Hollister, 1974).

In Hole 402A, the Aturian facies in the late Albian is marked by a cold episode $\left(\delta^{18} \mathrm{O}=0.5^{0} \% 0\right)$. By late Campanian (Cores 59 to 61 at Hole 400A) an increase in $\delta^{18} \mathrm{O}$ up to $0^{\%} \%$ is observed. The oxygen isotopic compositions remain quite stable $(\approx 0 \% 00)$ during the Maestrichtian; this value is comparable to that observed in the upper Maestrichtian at DSDP Site $398\left(\delta^{18} \mathrm{O}=\right.$ $-0.5^{0} \% 0$ ) where the $\delta^{18} \mathrm{O}$ values increase by $1^{\%} \%$ when passing from Hauterivian sediments to Maestrichtian ones (Létolle, in press). A similar climatic deterioration is recorded for Maestrichtian time in South Atlantic cores.

\section{Late Cretaceous/Paleocene Transition (Hole 400A, Site 401)}

This transition does not display any major change in the isotopic composition of bulk carbonates; this may indicate that no major oceanographic phenomenon occurred at that time.

\section{Cenozoic Isotopic Values}

During the Tertiary, temperature maxima occurred in the early Eocene and middle Miocene, and minima in the mid-late Eocene to Oligocene and late Neogene. 
TABLE 6

Oxygen and Carbon Isotopic Data for Bulk Carbonates From Site $401^{\mathrm{a}}$

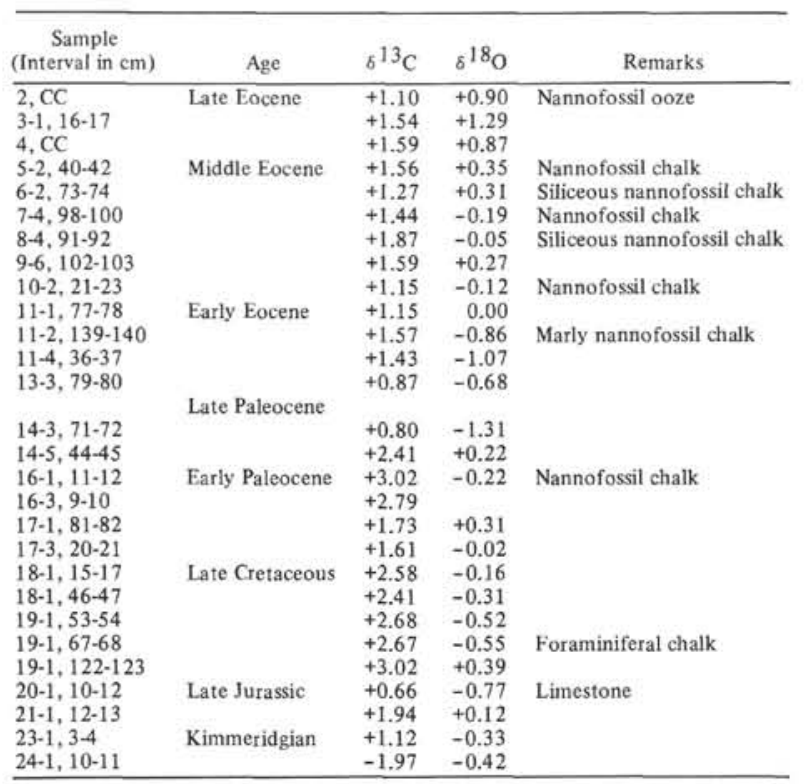

${ }^{\mathrm{a}}$ Expressed as deviation per mil from PDB.

TABLE 7

Oxygen and Carbon Isotopic Data for Bulk Carbonates From Hole $402 \mathrm{~A}^{\mathrm{a}}$

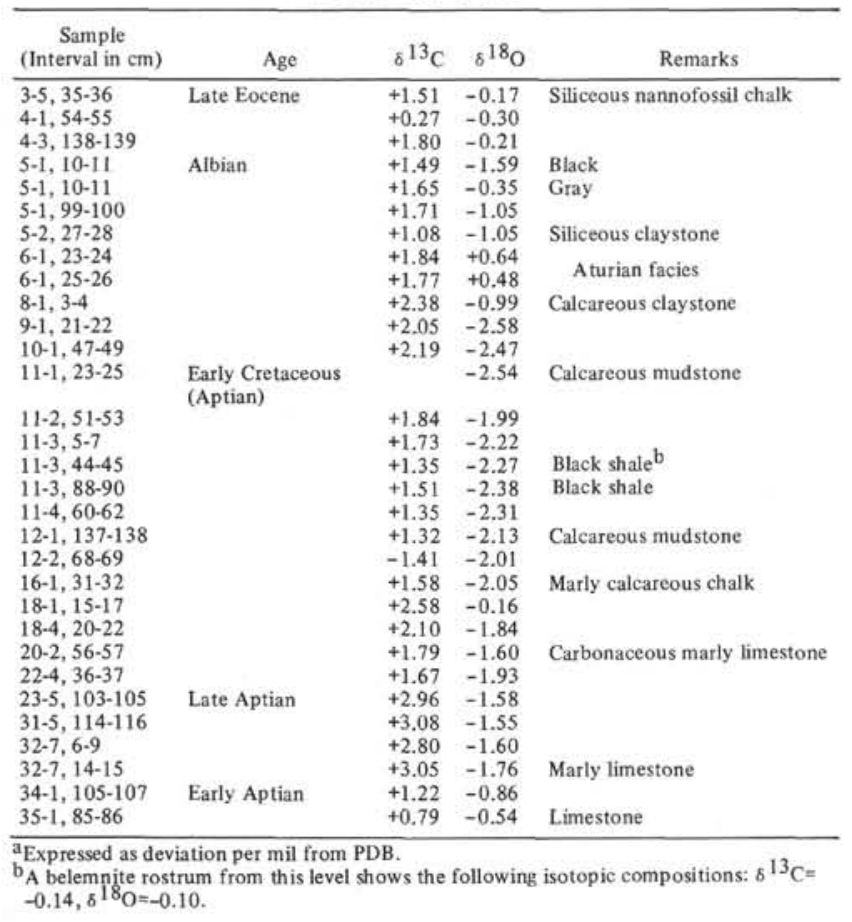

\section{Paleocene, Eocene, Early Oligocene Isotopic Values}

The isotopic compositions in the upper Paleocene and lowest Eocene samples are the lowest within the Tertiary sequence. They correspond to a warming episode that occurred through Zones P. 6 to P. 8 (Cores 57 to 54 in Hole $400 \mathrm{~A}$, Cores 13 to 11 in Site 401 ). Surface temperatures which can be deduced from the oxygen isotopic composition of the bulk carbonates as well as planktonic foraminifers range between 16 and $20^{\circ} \mathrm{C}$.
Some results from relatively short episodes are rather puzzling. For instance, at Hole $400 \mathrm{~A}$, presently located in deeper water than that of early Tertiary time, the oxygen isotopic values on the average are lower $(\approx 1 \%$ ) for bulk carbonates and for planktonic foraminifers than those measured for the same stratigraphic levels at Site 401. Further, in the period corresponding to Cores 11 to 9 ( 51 to $48 \mathrm{~m} . \mathrm{y}$.), the oxygen isotopic compositions measured on surface water material (Hole 400A and Site 401) are higher than those measured on benthic foraminifers. One explanation might be that diagenetic processes (dissolution, recrystallization) were responsible for change in the original isotopic signal. Because the effect of diagenesis on the isotopic compositions cannot be estimated, an evaluation of surface-to-bottom temperature gradient is probably not possible.

Following the above episode, a general trend towards increasing oxygen isotopic values is observed through the Eocene section; the average increase measured on bulk carbonates is $2.5 \%$ at Site $401,3.4 \%$ at Site 400 ; on benthic species it is $1.5 \%$ at Site 401 and $2.7 \%$ at Site 400; on planktonic species it is $1.7 \%$ at Site 401 .

The fact that such increases appear less important in the plankton of Site 401 than those measured in bulk carbonates could be explained by diagenetic dissolution processes altering the original isotopic composition of planktonic foraminiferal assemblages. It is not yet clearly understood why this isotopic increase appears systematically higher by about one per mil in Hole 400A.

Surface temperatures, evaluated from planktonic foraminifer analyses at Site 401 , were around $20^{\circ} \mathrm{C}$ in the late Paleocene-early Eocene and decreased to about $12^{\circ} \mathrm{C}$ in the late Eocene. Thus, the approximate temperature decrease experienced by North Atlantic surface water, in the Bay of Biscay, through the Eocene, was around $8^{\circ} \mathrm{C}$. Bottom temperatures decreased more regularly following the early Eocene, which corresponds in Hole 401A to a total $\delta^{18} \mathrm{O}$ increase of $1.5 \%$, equal to $6^{\circ} \mathrm{C}$. Bottom temperatures at both Hole $400 \mathrm{~A}$ and Site 401 were around $8^{\circ} \mathrm{C}$ in the early Oligocene.

This gradual decrease of temperature which affected the whole water column through the Eocene epoch might be related to the development of a deep circulation in the North Atlantic basin. The separation of Europe and Greenland (about 48-49 m.y. ago) and the formation of the North Atlantic basin allowed colder Arctic bottom water to flow into the North Atlantic and sink, thereby generating a deep cold water circulation pattern (Berggren and Hollister, 1974). The phenomenon preceded the establishment of the psychrosphere at $38 \mathrm{~m} . \mathrm{y}$.

With the development of a deep circulation in the North Atlantic basin, upwelling developed, contributing large amounts of nutrients in the euphotic zone; an increasing productivity might have resulted in lower ${ }^{13} \mathrm{C}$ contents in biogenous carbonates (Figure 3).

\section{Oligocene Isotopic Values}

Statistically reliable information for the Oligocene samples is meager.

During the early Oligocene, the values obtained for bottom temperatures appear to be around $8^{\circ} \mathrm{C}$. This is higher 
TABLE 8

Oxygen and Carbon Isotopic Data for Bulk Carbonates at Sites 403 and $404^{\text {a }}$

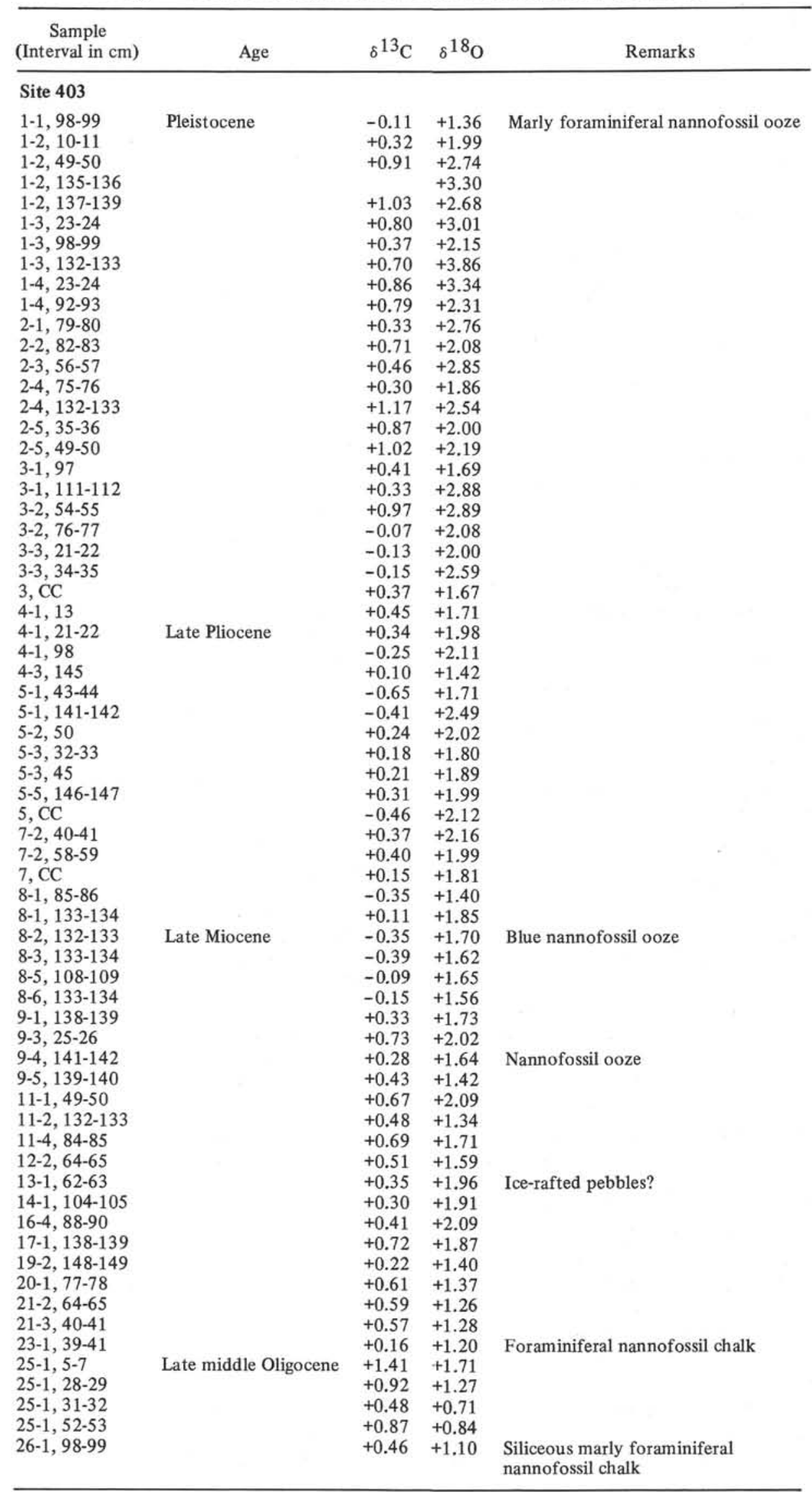


TABLE 8 - Continued

\begin{tabular}{lllll}
\hline $\begin{array}{c}\text { Sample } \\
\text { (Interval in cm) }\end{array}$ & Age & $\delta^{13} \mathrm{C}$ & $\delta^{18} \mathrm{O}$ & \multicolumn{1}{c}{ Remarks } \\
\hline $26-1,116-118$ & & +0.56 & +1.20 & \\
$26-2,116-118$ & & +0.41 & +1.39 & \\
$26-3,100-102$ & & +0.64 & +1.20 & \\
$26-3,120-122$ & & +0.72 & +0.06 & \\
$26-4,12-13$ & & +1.07 & +0.16 & \\
$27-1,5-6$ & Middle Eocene & +0.80 & +0.11 & Siliceous nannofossil chalk \\
$27-1,29-31$ & & +0.13 & -0.31 & \\
Site 404 & & & & \\
$1-5,115-116$ & Pleistocene & +1.14 & +2.26 & Marly foraminiferal nannofossil ooze \\
$1-6,49-50$ & & +1.11 & +2.62 & \\
$2-3,26-27$ & Late Pliocene & +1.48 & +1.87 & \\
\hline
\end{tabular}

${ }^{\mathrm{a}}$ Expressed as deviation per mil from PDB.

by $2^{\circ}$ to $3^{\circ} \mathrm{C}$ than the values proposed by Boersma and Shackleton (1978) for the equatorial Atlantic in Hole 366A. For the Pacific Ocean, a few values are given by Douglas and Savin (1973) and correspond to a temperature range of $2^{\circ}$ to $4^{\circ} \mathrm{C}$ (assuming the ocean isotopic composition to be $-1.2 \%$ )

It thus appears that there may have been significant temperature differences between the deep waters of the equatorial Pacific and Atlantic on one hand, and between the deep water of the equatorial and North Atlantic on the other. Evidently, the cold Antarctic water masses that were entering the Pacific and the Atlantic at that time were not able to penetrate as far north in the Atlantic as in the Pacific because of the physiography of the former. This could explain why, in the North Atlantic, deep temperatures which were essentially determined by Arctic deep circulation, were higher than that of other oceans (Pacific and South Atlantic).

\section{Miocene Isotopic Values (Hole 400A and Sites 403, 406)}

The ${ }^{18} \mathrm{O} /{ }^{16} \mathrm{O}$ ratios of the bulk carbonates start to increase progressively during the late Oligocene. Some differences are observed between the different sites. During the middle Miocene, averaged $\delta^{18} \mathrm{O}$ values are different, being +0.4 $\pm 0.5 \%$ at Site 406 and $+1.2 \pm 0.8 \%$ at Site 403 . Values corresponding to the mid-late Miocene do not display any great variations, but remain steady through the upper Miocene and lower Pliocene samples with the following averages: $+1.2 \pm 0.3 \%$ for Site $406,+1.4 \pm 0.3 \%$ for Hole $400 \mathrm{~A}$, and $+1.7 \pm 0.3 \%$ for Site 403 .

Bottom temperatures increased during the early and middle Miocene. The amplitude of this increase however $\left(10^{\circ}\right.$ equivalent to a $\delta$ variation of $2.5^{\circ} \% 0$ ) appears unrealistic; it should imply a strong modification in the deep water circulation. The increase correlates well with one of the same geologic time reported by Douglas and Savin (1973) in the Central Pacific (Site 167), the amplitude of which is only $3.5^{\circ} \mathrm{C}$. One may argue that diagenetic processes which affected the calcitic material in that part of the sedimentary sequence of Hole $400 \mathrm{~A}$ changed the original isotopic composition.

A global increase of $1 \%$ is to be observed between the early Miocene $\delta^{18} \mathrm{O}$ values and the $11 \mathrm{~m} . \mathrm{y} . \delta^{18} \mathrm{O}$ values (Zones N.15, N.16). This increase could be related to the major accumulation of the Antarctic continental ice sheet.
Assuming an increase in $\delta^{18} \mathrm{O}$ of ocean water around $0.9^{0} \%$ due to Antarctica glaciation (Shackleton and Kennett, 1975), the bottom temperatures at that time were on the order of $5.5^{\circ} \mathrm{C}$. Following temperatures rise at the end of the Miocene, there is a progressive increase in ${ }^{18} \mathrm{O} /{ }^{16} \mathrm{O}$ ratios.

Thermal evolution of surface water parallels closely that of bottom waters. A drop near the N.15 zone (11 m.y.) correlates well with the contemporaneous drop for bottom waters. During this colder episode, the decrease in ${ }^{13} \mathrm{C}$ content of the surface dwelling calcitic organisms may be related to an increase in productivity and nutrients. There is some indication that surface waters warmed during the late Miocene (temperatures around $18^{\circ} \mathrm{C}$ ), a feature also apparent in the Pacific curve of Shackleton and Kennett (1975).

\section{Pliocene and Pleistocene Isotopic Values}

Through the Pliocene the oxygen isotopic compositions of bulk carbonates display, on the average, a progressive shift towards higher values, reaching values around $2 \%$ in Core 7 (Hole 400A) at a time marked by the onset of northern glaciations at 2.6 m.y. (Shackleton and Kennett, 1975). During the Pleistocene, many large oscillations occur in less than one million years. The amplitude of these oscillations is about $2.7^{\circ} \%$, i.e., twice the major $\delta^{18} \mathrm{O}$ range observed by Shackleton and Opdyke (1976) in Core V $28 / 239$ from the equatorial Pacific. Such a large amplitude may be explained by the immediate proximity of the northern ice caps at that time (McIntyre et al., 1976). ${ }^{18} \mathrm{O} /{ }^{16} \mathrm{O}$ ratios in benthic and planktonic foraminifers (Hole $400 \mathrm{~A}$ ) also increase regularly through the Pliocene, and display large variations in the Pleistocene. Although only a few samples were analyzed, it can be predicted that the major $\delta^{18} \mathrm{O}$ range registered by benthic foraminifers, which is around $1.4 \%$, clearly represents the isotopic effect resulting from the accumulating ice on northern continents. The higher $\delta^{18} \mathrm{O}$ variations which are displayed by planktonic foraminifers during the Pleistocene at Hole $400 \mathrm{~A}$ (from $-1 \%$ to $+2.2 \%$ ) and which are similar to that of bulk carbonates, reflect temperature and isotopic variations in surface waters. The temperature effect (corresponding to $3.2^{\%} \%$ minus $1.4^{0} \%=1.8 \%$ in $\delta^{18} \mathrm{O}$ variations) could have been as high as $7.5^{\circ} \mathrm{C}$. McIntyre et al. (1976) evaluated a summer temperature around $8^{\circ} \mathrm{C}$ in surface water 18,000 years B.P. at the latitudes of Sites 400 and 
TABLE 9

Oxygen and Carbon Isotopic Data for Bulk Carbonates at Site $406^{\mathrm{a}}$

\begin{tabular}{|c|c|c|c|c|}
\hline $\begin{array}{l}\text { Sample } \\
\text { (Interval in } \mathrm{cm} \text { ) }\end{array}$ & Age & $\delta^{13} \mathrm{C}$ & $\delta^{18} \mathrm{O}$ & Remarks \\
\hline $1-1,22-23$ & Pleistocene & +0.41 & +1.42 & Foraminiferal nannofossil ooze \\
\hline $1-1,60-61$ & & +0.23 & +1.28 & \\
\hline $1-1,117-118$ & & +1.32 & +3.01 & \\
\hline $1-1,120-121$ & & +1.11 & +1.85 & \\
\hline $1-2,6-7$ & & +1.68 & +3.06 & \\
\hline $1-2,40-41$ & & & +1.61 & \\
\hline $1-2,120-121$ & & +1.44 & +2.86 & \\
\hline $1-3,12-13$ & & +1.57 & +2.86 & \\
\hline $1-3,59-60$ & & +1.12 & +1.98 & \\
\hline $1-3,114-115$ & & +2.19 & +3.57 & \\
\hline $1-3,117-118$ & & +1.27 & +3.01 & \\
\hline $1-4,27-28$ & & +1.26 & +3.11 & \\
\hline $2-2,137-138$ & & +1.11 & +2.28 & Marly foraminiferal nannofossil ooze \\
\hline $2-3,60-61$ & & +1.11 & +2.16 & \\
\hline $2-3,72-73$ & & +0.70 & +2.11 & \\
\hline $2-4,70-71$ & & +0.53 & +2.54 & Nannofossil ooze \\
\hline $3-1,121-122$ & Pliocene & +0.34 & +2.04 & \\
\hline $4-1,101-102$ & Early Pliocene & +0.42 & +1.19 & \\
\hline $6-2,100-102$ & Late Miocene & +0.37 & +1.38 & Nannofossil chalk \\
\hline $7-1,18-20$ & & +0.68 & +0.46 & \\
\hline $7-3,11-13$ & & +0.32 & +1.23 & \\
\hline $8-1,41-43$ & & +0.29 & +0.91 & \\
\hline $8-4,119-120$ & & +0.56 & +1.05 & \\
\hline $9-1,99-100$ & & +0.85 & +1.01 & \\
\hline $10-1,66-67$ & & +2.60 & +1.57 & \\
\hline $11-1,78-79$ & & +1.10 & +1.17 & \\
\hline $12-2,17-19$ & & +0.98 & +1.05 & \\
\hline $13-5,40-42$ & & +1.02 & +1.10 & \\
\hline $14-1,83-86$ & & +1.08 & +0.92 & \\
\hline $15-1,72-74$ & & +1.09 & +0.92 & Foraminiferal nannofossil chalk \\
\hline $15-2,77-78$ & & +1.71 & +1.81 & \\
\hline $16-2,134-136$ & & +1.36 & +1.45 & \\
\hline $16-3,44-45$ & & +1.51 & +1.13 & \\
\hline $17-2,20-21$ & & +1.59 & +1.34 & \\
\hline $20-2,124-128$ & Middle Miocene & +1.42 & +0.36 & \\
\hline $22-1,28-30$ & & +1.58 & +0.30 & \\
\hline $23-1,71-73$ & & +1.41 & -0.04 & \\
\hline $23-4,53-57$ & & +1.11 & -0.13 & \\
\hline $24-2,57$ & & +0.97 & -0.23 & \\
\hline $26-1,9-10$ & & +1.10 & +0.23 & Calcareous diatomite \\
\hline $26-2,123-125$ & & +1.87 & +0.63 & $\begin{array}{l}\text { Sample not quoted on shipboard } \\
\text { report }\end{array}$ \\
\hline $27-1,3-6$ & Early Miocene & +0.35 & -0.86 & Diatomite chalk \\
\hline $28-2,11-13$ & Late Oligocene & +0.69 & -0.40 & \\
\hline $29-1,74-77$ & & +0.65 & -0.62 & \\
\hline $29-5,19-20$ & & +0.39 & -1.21 & Calcareous chalk \\
\hline $30-3,45-47$ & Late-middle Oligocene & +0.81 & -0.90 & Siliceous chalk \\
\hline $31-1,40-42$ & & +0.71 & -0.70 & \\
\hline $32-3,17-18$ & & +0.57 & -0.68 & \\
\hline $32, \mathrm{CC}$ & & +0.76 & -0.60 & \\
\hline $34-1,39-41$ & & +0.60 & -0.39 & \\
\hline $35-2,7-10$ & & +0.39 & -0.13 & Calcareous chalk \\
\hline $36-2,7-10$ & & +0.65 & -1.31 & \\
\hline $36-2,55-56$ & & +0.59 & +0.69 & Foraminiferal nannofossil chalk \\
\hline $37-2,70-72$ & & +0.63 & -1.81 & \\
\hline $37-5,32-35$ & & +1.14 & -2.86 & \\
\hline $38-4,131-134$ & & +1.25 & -1.79 & Diatomaceous mudstone \\
\hline $39-4,53-56$ & & +0.97 & -2.41 & $\begin{array}{l}\text { Calcareous chalk interbedded with } \\
\text { diatomite chalk }\end{array}$ \\
\hline $40-3,97-98$ & & +1.21 & -2.56 & Marly limestone \\
\hline $41-6,75-76$ & & +1.07 & -2.29 & \\
\hline $42-3,68-71$ & & +0.38 & -1.20 & \\
\hline $45-5,10-12$ & Late Eocene & +0.98 & -1.17 & Nannofossil limestone \\
\hline $47-2,73-75$ & Middle Eocene & +1.11 & -2.63 & Calcareous claystone \\
\hline $48-4,49-52$ & & +0.44 & -2.21 & \\
\hline
\end{tabular}

${ }^{\mathrm{a}}$ Expressed as deviation per mil from $\mathrm{PDB}$. 


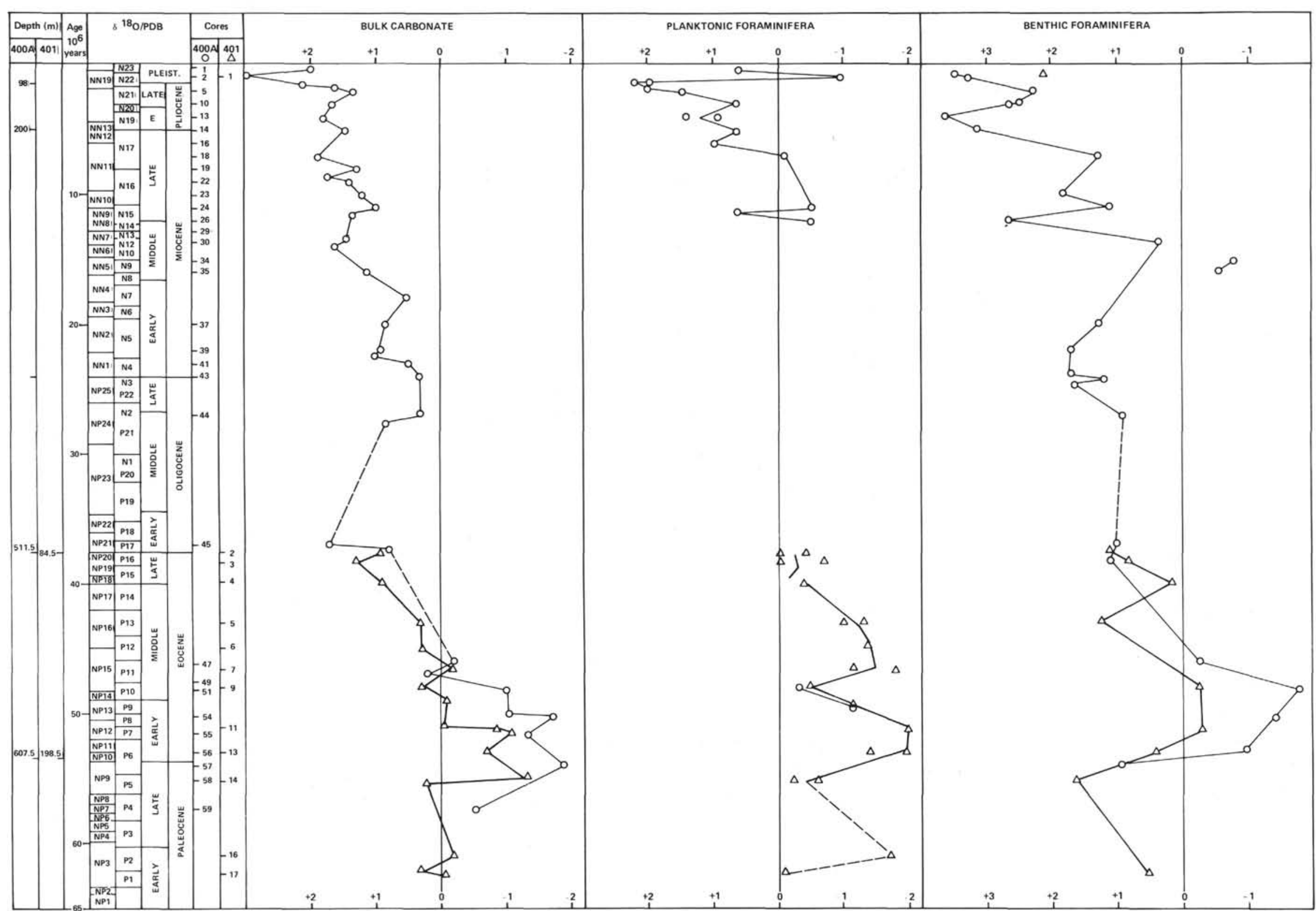

Figure 2. Oxygen isotopic compositions of bulk carbonates, planktonic foraminifers, and benthic foraminifers as a function of depth in Holes $400 \mathrm{~A}$ and 401 . 


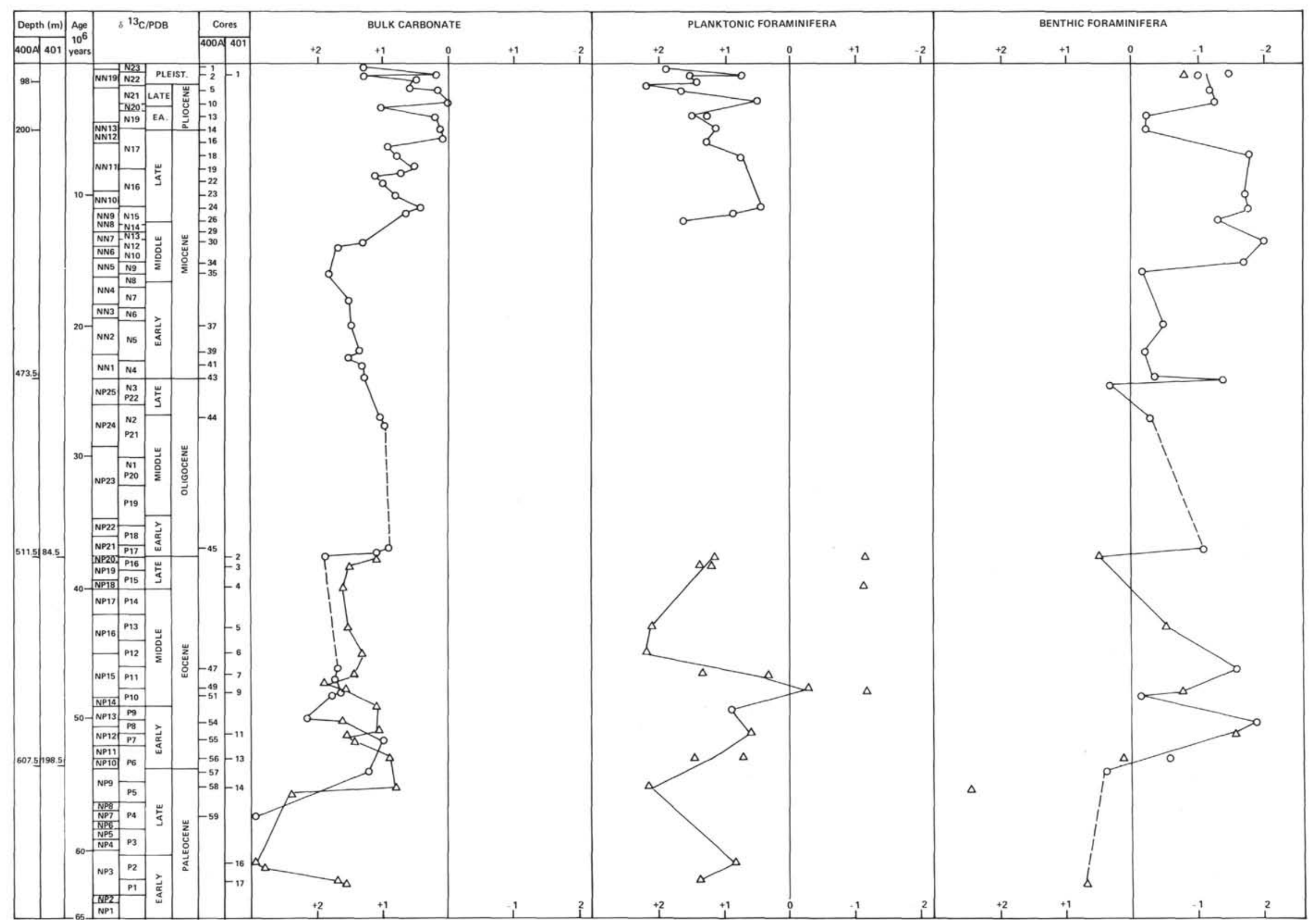


R. LÉTOLLE, C. VERGNAUD GRAZZINI, C. PIERRE

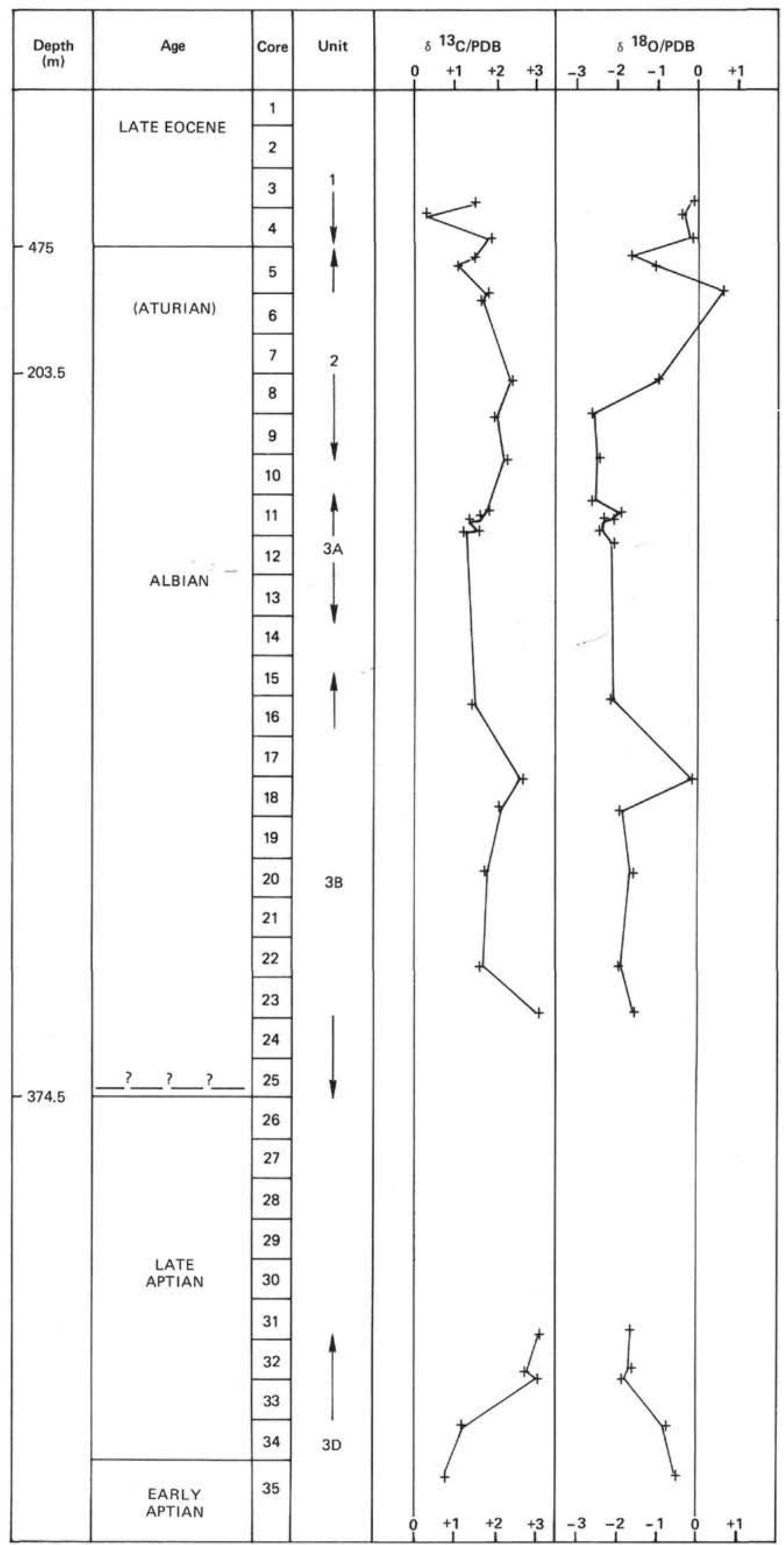

Figure 4. Oxygen and carbon isotopic compositions of bulk carbonates in Hole $402 A$ as a function of depth. 


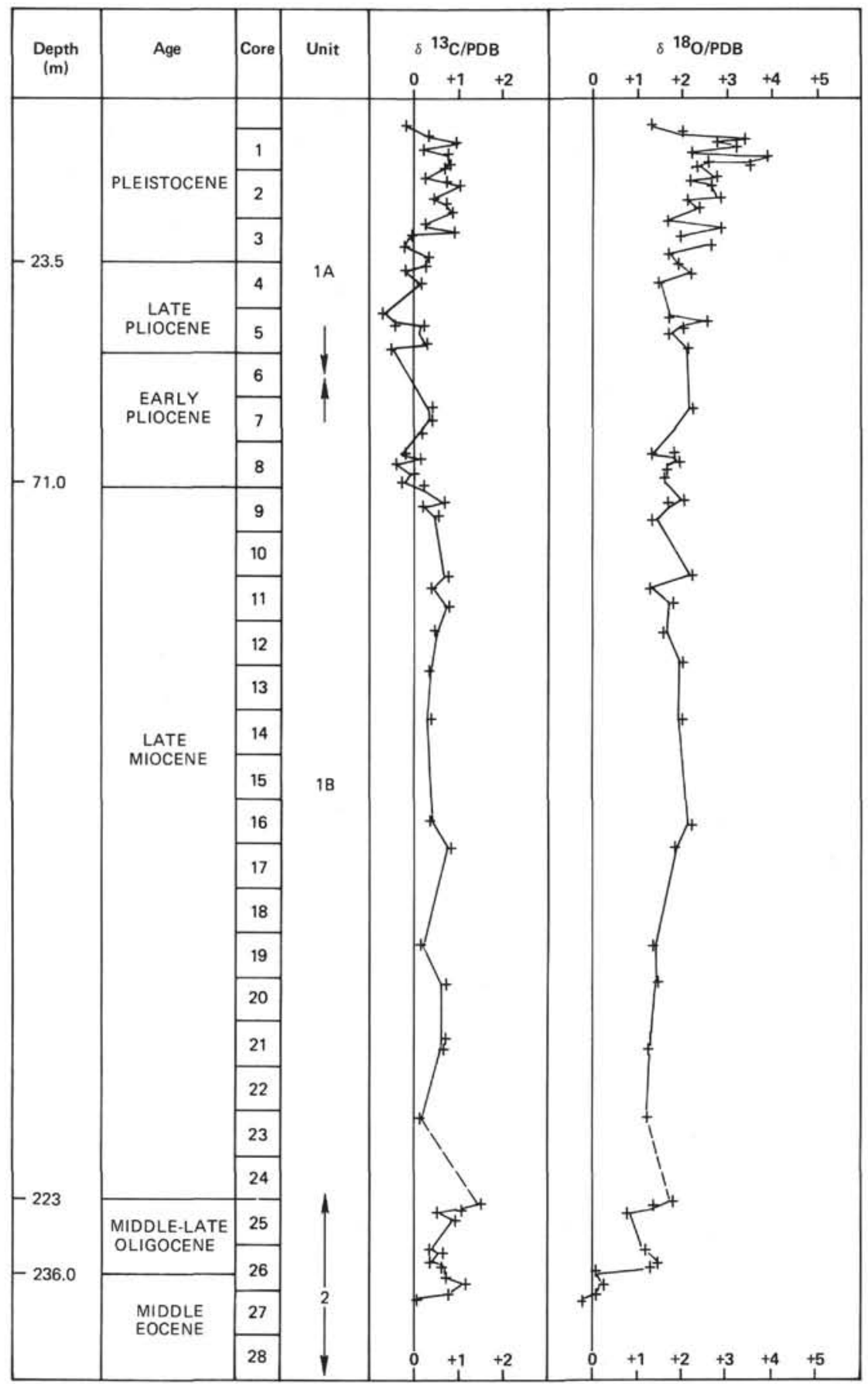

Figure 5. Oxygen and carbon isotopic compositions of bulk carbonates at Site 403 as a function of depth.

401. This represents a lowering of $8^{\circ} \mathrm{C}$ compared with present summer temperatures at those latitudes. Thus, $\delta^{18} \mathrm{O}$ variations as high as $3 \%$ in planktonic material can readily be explained in the mid latitudes of the North Atlantic.

\section{SUMMARY (FIGURES 7, 8)}

During Late Cretaceous to early Eocene, a slight decrease in the oxygen isotopic compositions of the bulk carbonates indicates a warming of the climate. In the middle Eocene, the increase in $\delta^{18} \mathrm{O}$ values corresponds to a cooling related to the establishment of a deep water circulation in the North
Atlantic basin. The concomitant decrease in $\delta^{13} \mathrm{C}$ may be explained by an increase in the productivity due to influxes of nutrients by the cold water masses.

This paleoclimatic pattern is general for all the studied sites, if we except a part of the section at Site 406 . At that site, during the Eocene until the beginning of the late Miocene, the $\delta$ values are systematically lower than at the other sites. The sediments of this period (lithologic Units 5 to $2 \mathrm{~B}$ ) are characterized by a low $\mathrm{CaCO}_{3}$ content which is interpreted to be a result of dissolution (see Site Chapter, this volume). Whether the low $\delta^{18} \mathrm{O}$ values may be the result 
R. LÉTOlLE, C. VERGNAUd GRAZZINI, C. PIERRE

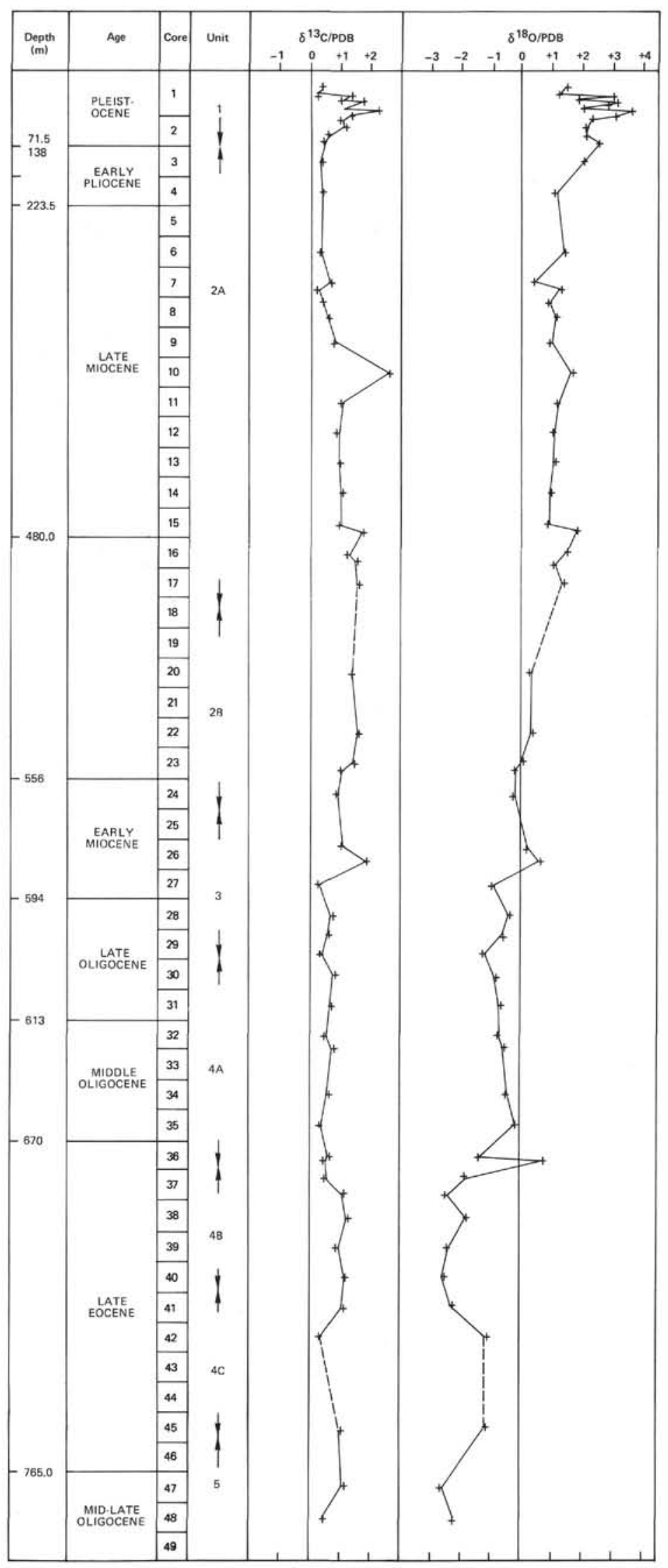

bonates at Site 406 as a function of depth. 


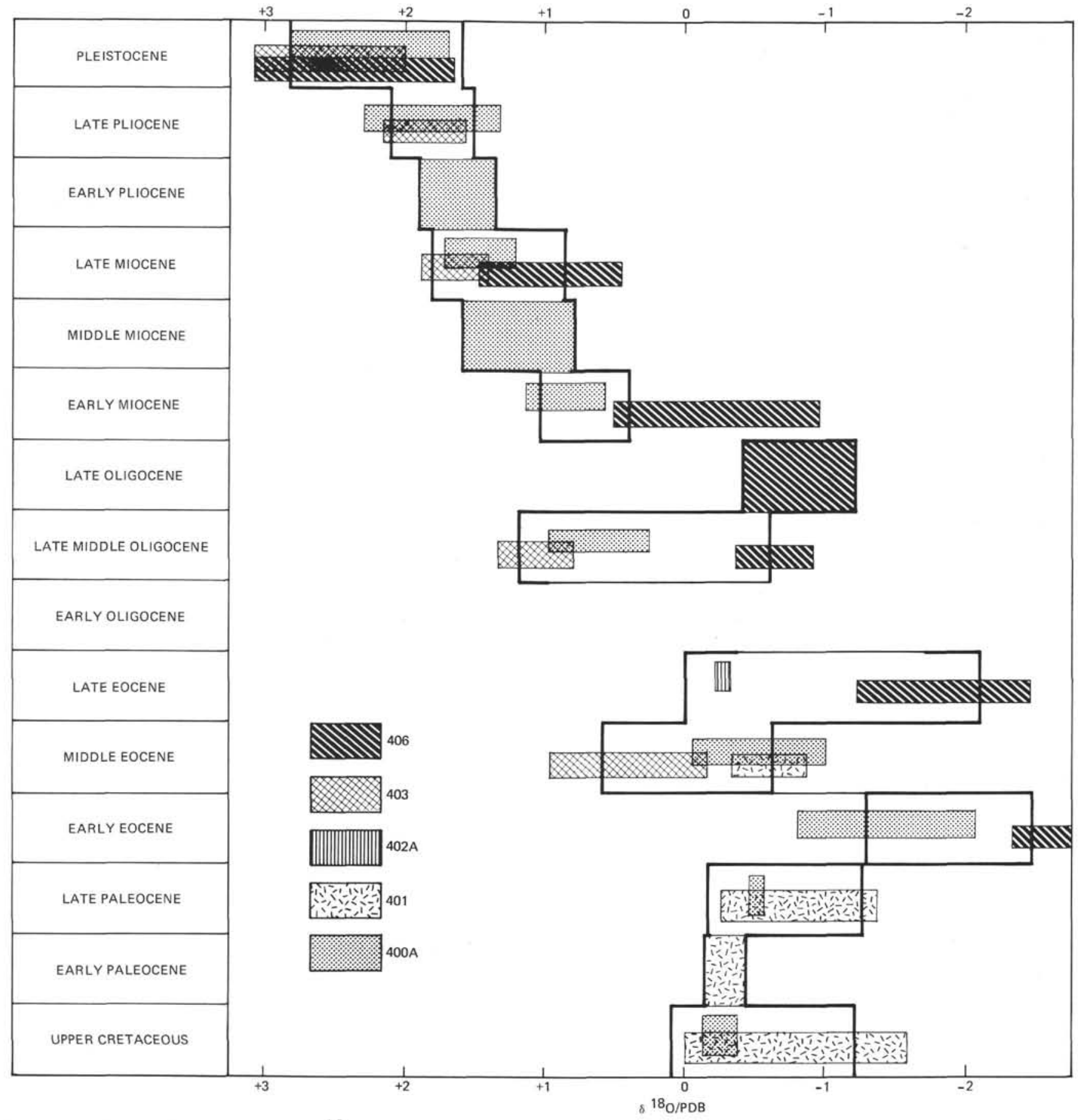

Figure 7. Mean of isotopic data for ${ }^{18} \mathrm{O}$ on bulk carbonates for each site (the heavy box corresponds to the overall mean of analyzed samples for each geological stage).

of diagenetic dissolution and/or recrystallization, or an indication of warmer surface waters in the North Atlantic, presently cannot be stated. The latter hypothesis is difficult to support since the same warm effect for Site 403, at a similar latitude, would be expected. On the contrary, the isotopic effect of recrystallization (even partial) at a temperature depending on the geothermal gradient might well explain some of the isotopic differences which exist at the two adjacent sites. For instance, upper Miocene sediments of Site 406 , buried beneath 500 meters of younger sediments, are submitted to a temperature around $26^{\circ} \mathrm{C}$. Total recrystallization at this temperature in water with $\delta^{18} \mathrm{O} \simeq 1 \%$ would lead to a carbonate with an oxygen isotopic composition around $-3 \%$.

Strontium data for Hole 400A (Renard and Létolle, this volume) indicate that, before Oligocene time, decreasing strontium content should be correlated with diagenetic recrystallization. Because it is difficult to estimate the relative importance of the recrystallization, and the physical and the geochemical conditions under which it occurred, 


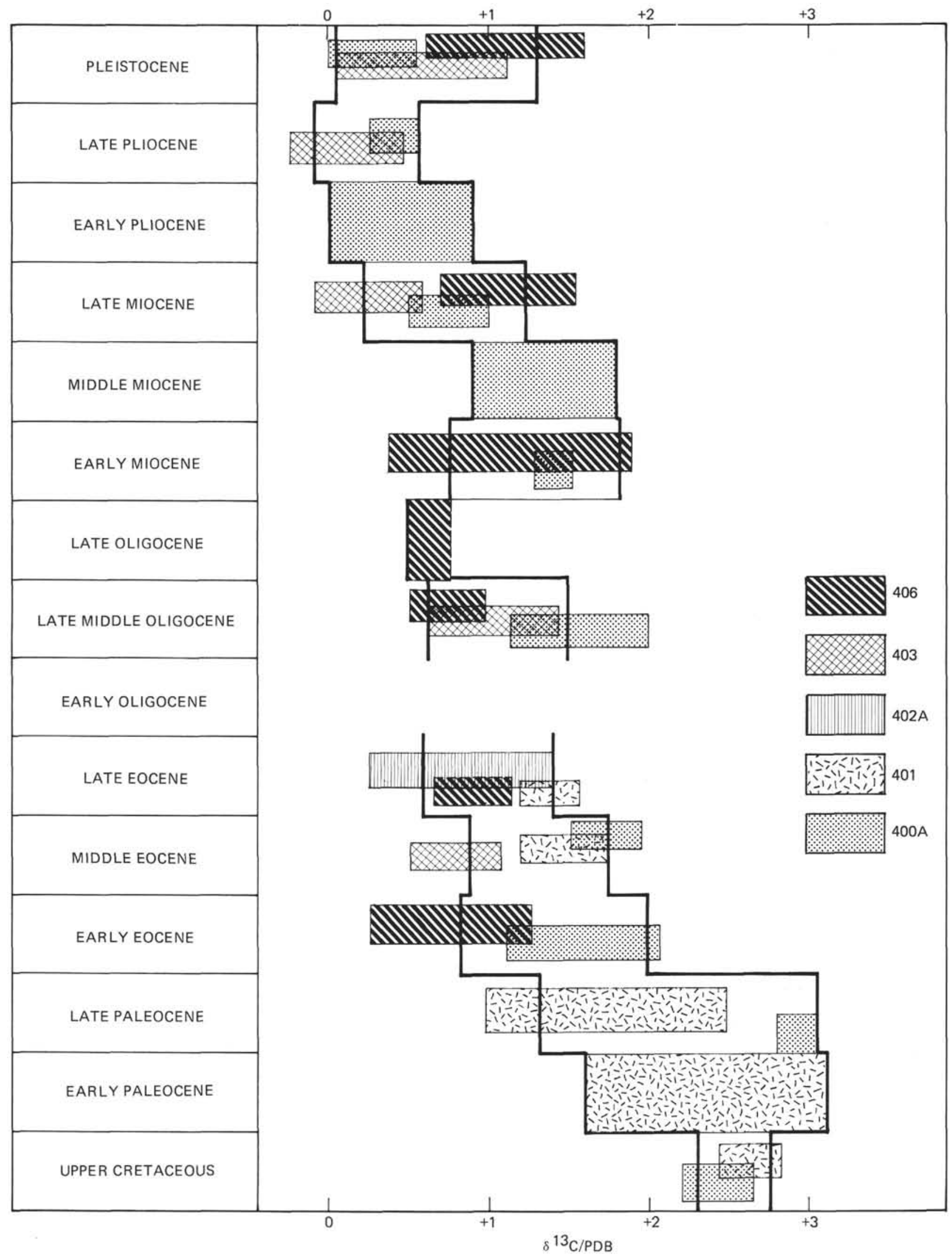

Figure 8. Mean of isotopic data for ${ }^{13} \mathrm{C}$ on bulk carbonates for each site (the heavy box corresponds to the overall mean of analyzed samples for each geological stage). 
further interpretation of the differences observed in the isotopic record in the different sites is not feasible.

\section{ACKNOWLEDGMENTS}

Funds for this research were provided by CNRS through ATP-IPOD, Grant 26-86.

The authors greatly acknowledge Dr. C. Müller, D. Schnitker, and L. Montadert for stimulating discussions and for supplying samples, and Dr. J. Killingley for reading and criticizing the original manuscript. Thanks are extended to A. Filly and M. Dudouyt for laboratory assistance.

\section{REFERENCES}

Berggren, W.A. and Hollister, C.D., 1974. Paleogeography, paleobiogeography and the history of circulation in the Atlantic Ocean. In Hay, W.W. (Ed.), Studies in paleo-oceanography: Tulsa. Soc. Econ. Paleontol. Mineral., Spec. Publ. 20, p. $126-186$.

Boersma, A. and Shackleton, N., 1978. Oxygen and carbon isotope record through the Oligocene, DSDP Site 366, equatorial Atlantic. In Lancelot, Y., Seibold, E., et al., Initial Reports of the Deep Sea Drilling Project, v. 41: Washington (U.S. Government Printing Office), p. 957-962.

Brenneke, J.C., 1978. A comparison of the stable oxygen and carbon isotope composition of Early Cretaceous and Late Jurassic carbonates from Sites 105 and 367. In Lancelot, Y., Seibold, E., et al., Initial Reports of the Deep Sea Drilling Project, v. 41: Washington (U.S. Government Printing Office), p. 937-956.
Douglas, R.G. and Savin, S.M., 1973. Oxygen and carbon isotope analyses of Cretaceous and Tertiary Foraminifera from the Central North Pacific. In Winterer, E.L., Ewing, J.I., et al. Initial Reports of the Deep Sea Drilling Project, v. 17: Washington (U.S. Government Printing Office), p. 591-605.

Létolle, R., Renard, M., Bourbon, M., and Filly, A., in preparation. Oxygen 18 and carbon 13 of Leg 44 carbonates: a comparison with the alpine series.

Létolle, R., in press. Oxygen 18 and carbon 13 isotope ratios from bulk carbonate samples. In Ryan, W.B.F., Sibuet, et al., Initial Reports of the Deep Sea Drilling Project, v. 47, Part 2: Washington (U.S. Government Printing Office).

McIntyre, A., Kipp, N.G., Be, A.W.H., Crowley, T., Kellogg, T., Gardner, J.V., Prell, W., and Ruddiman, W.F., 1976. Glacial North Atlantic 18,000 years ago, a climap reconstitution, Geol. Soc. Am. Mem. 145, p. 43-76.

Margolis, S.V., Kroopnick, P.M., Goodney, D.E., Dudley, W.C., and Mahoney, M.E., 1975. Oxygen and carbon isotopes from calcareous nannofossils as paleooceanographic indicators, Science, v. 189, p. 555-557.

Shackleton, N. and Kennett, J.P., 1975. Paleotemperature history of the Cenozoic and the initiation of Antarctic glaciation: oxygen and carbon isotope analyses in DSDP Sites 277, 279 and 281. In Kennett, J.P., Houtz, R.E., et al., Initial Reports of the Deep Sea Drilling Project, v. 24: Washington (U.S. Government Printing Office), p. 743-755.

Shackleton, N.J. and Opdyke, N.D., 1976. Oxygen-Isotope and paleomagnetic stratigraphy of Pacific Core V28-239 late Pliocene to latest Pleistocene, Geol. Soc. Am. Mem. 145, p. 449-464. 